\title{
The Adversity Quotient (Control, Origin \& Ownership, Reach, and Endurance) and its Relationship Toward Entrepreneurial Intention: A Study on Student in Faculty of Economics \& Business Universitas Sumatera Utara
}

\author{
Bongsu Hutagalung, \\ Faculty of Economics and Business \\ Universitas Sumatera Utara \\ Medan, Indonesia \\ Muhammad Irsyad Tamimi \\ Faculty of Economics and Business \\ Universitas Sumatera Utara \\ Medan, Indonesia \\ Email: irsyad.tamimi@outlook.com
}

\author{
Yasmin Chairunisa Muchtar, \\ Faculty of Economics and Business \\ Universitas Sumatera Utara \\ Medan, Indonesia \\ Ami Dilham, Arif Qaedi Hutagalung \\ Faculty of Economics and Business \\ Universitas Sumatera Utara \\ Medan, Indonesia
}

\begin{abstract}
This study aimed to analyze the effect of control, origin \& ownership, reach, and endurance on the entrepreneurial intention. The population and sample in this study were students in The Faculty of Economics and Business University of North Sumatera batch 2013 and 2014 majoring in entrepreneurship up to 90 respondents. Data is analyzed by multiple linear regression analysis. Results showed that partially control and endurance have significant influence on entrepreneurial intention. Meanwhile, origin \& ownership as well as reach variable have insignificant effect on entrepreneurial intention. However control, origin \& ownership, reach, and endurance simultaneously have significant effect on entrepreneurial intention. The coefficient of determination is 0.304 . It means that adversity quotient contributed $30.4 \%$ in explaining the entrepreneurial intention on students in The Faculty of Economics and Business University of North Sumatera, while the rest $69.6 \%$ is explained by others.
\end{abstract}

Keywords: adversity quotient, control, origin \& ownership, reach, endurance, entrepreneurial intention

\section{INTRODUCTION}

At this time, most people have dreams to become entrepreneur. [1] believes many of the young people dreaming to become young entrepreneur but they are still not entirely sure to move into the next step, because they feel difficult in facing various obstacles that may occur. The hard thing to become an entrepreneur is not to create his dream but in make decision, because [2] said there are five step must be passed if someone wants to become an entrepreneur such as make decision, start, build, promote, and realize. That difficulty in making decision caused by most people believed several myths that flourish in society. The people always give unrealistic reasons why they do not choose the entrepreneur as their career like they said having no capital, no experience, no fixed amount of income, irregular working hours, and being an entrepreneur must drain his mind and energy. An entrepreneur is like fighter who must be on guard against an uncertain situation, but that is the attraction and challenge from being the entrepreneur because becoming an entrepreneur requires perseverance, seriousness, and a high will, and also the risk is higher than other jobs[3]. That is often a consideration to them before deciding to become an entrepreneur. No matter what kind of job their has, they will be facing obstacles in the implementation as well as in entrepreneurship, so what is needed for someone to solving the obstacles that prevent them for achieving their goals is to improve the quality their adversity quotient, because adversity quotient is some capability that all people has to solving obstacles by using their intelligence.

In 1997, Paul G. Stoltz proposed a new concept of intelligence that emphasized the response of a person to facing obstacles. To become entrepreneur that is fulfilled with various obstacles needed the person who can control themselves as well, responsibly, and have strong endurance in facing obstacles that exist in the entrepreneurial environment [4]. That is similar with theory adversity quotient because it has its forming dimensions known as CO2RE [5]. Control is a person's ability to feel his capabilities for facing obstacle that prevent him from reaching his goals. Origin \& Ownership is a person's awareness in acknowledging and assigning responsibility from some problem. Reach is a person's ability to limit the problems he faces. Endurance is the resistance that person has in facing obstacles. [4,6] reveal the low entrepreneurial intention has owned the people is caused by several factors such as afraid to take risks, afraid to failure, not 
have business capital, doubt with their ability, not ready to face obstacles that exist, and their resistance has less trained. According to Hisrich et al [1] entrepreneurial intention is one motivational factor that encourages a person to become entrepreneur, because the intention reflects a person's determination to perform an action, by having a good quality adversity quotient, then the existing obstacles will not be able to hinder person in realizing its purpose [7].

\section{LITERATURE REVIEW}

\section{A. Entrepreneurial Intention}

In the entrepreneurial literature, the most important factors that created the entrepreneurial intention are psychological factors. Psychological factors explain the pattern of act through intention of choosing entrepreneur as a career. The intention indicates the amount of the person effort will be initiated to starting the business. The entrepreneurial intention is a person's commitment to start new business and it is a central issue that needs to be considered in understanding the entrepreneurial process [8]. According to Krueger et al [9] explained the person who has an intention of starting a new business will have better readiness, because the entrepreneurial intention is a reliable predictor to measure entrepreneurial behavior. Those psychological factors are:

1) Self determination

Self determination is an individual belief that he has autonomy and control over how to do his job [10].

2) Risk-bearing ability

This factor mean risk bearing ability is an individual's capabilities to solve various challenge in an effort to achieve its goals [10]

3) Beliefs and attitude

Beliefs and attitude plays an important role in a person when making decisions to become entrepreneur [10]

\section{B. The Relationship Adversity Quotient With Entrepreneurial Intention}

According to Stoltz [5] adversity quotient is the ability to face any obstacles and turn them into opportunities. Adversity quotient is used to help individuals strengthen their ability and perseverance to facing various obstacles while holding on the principles and dreams that are the main goal. Sometimes there is a statement "why some people can survive and continue struggling in a difficult situation while other people who have a high IQ and EQ still fail and give up?" [11]. Adversity quotient can be the right answer to overcome such situation. In fact, the difficulties faced will be a trigger to strengthen the determination and entrepreneurial intention. That result are supported by Riyanti's opinion [12] who said adversity quotient closely related on the entrepreneurial process because to become an entrepreneur requires the courage to face failure and have a strong desire to try repeatedly until successful.

\section{The Relationship Control With Entrepreneurial Intention}

The key from this dimension is "to feel", because control is a first dimension for adversity quotient that questions the extent to which person can feel themselves able to overcome obstacles that prevent them from reaching their goal [5] Krueger et al [9] argue that a person who can feels himself capable to overcoming the obstacles in entrepreneurial environment indicates a strong confidence and optimistic person for achieving his goals. According to Stoltz [5] the person who have low control feel themselves unable to change the bad situation they are facing. The person tends to despair when overcoming obstacles because he feels unable to do anything, then it will affect the entrepreneurial intention. The level of control that comes from inside or outside, so it is not easily affected, and is always confident in making a decision [11].

\section{The Relationship Origin \& Ownership With Entrepreneurial Intention}

Origin \& ownership are the acknowledgments of the difficulties encountered. This explains that the difficulty comes from the individuals themselves, so that the developing individuals will admit their mistakes and not exaggerate the mistakes [11]. According to Stoltz [5] origin questioned what was the source of the problem. Stoltz [5] says the person who has a low origin, think of themselves as the only one cause of a problem, which will cause excessive fear to obstacles, it will certainly reduce its intensity. In line with the origin, ownership dimension questions how much a person is willing to give responsibility to a problem. Ownership provides an important role in building the entrepreneurial intention, a great sense of responsibility gives courage to person for commit to making decisions, when making the decision there is no fear of regret in the future. Ownership help person to redefine accountability in highly constructive and practical terms [13]. So the origin and ownership refers to guilt from within a person and willing to account for the obstacles that are facing.

\section{E. The Relationship Reach With Entrepreneurial Intention}

According to [11] reach is about how far a difficulty encountered can influence his life. Reach explores how far the difficult situation go inti other areas of person life. Reach determines how large the person perceive the problem to be, or its apparent extent. Logically, the larger the problem appears, the greater its potential to induce fear, helplessness, apathy, and inaction [13]. Stoltz [5] z says the lower reach can make people think the obstacles like disaster; they don't have a good peace of mind otherwise the higher reach can stay focus to reaching their goals and will not give up if it fails.

\section{F. The Relationship Endurance With Entrepreneurial Intention}

Endurance describes a person's strength in overcoming obstacles. Endurance dimension assesses and explains how long one perceives the adversity will endure. Those with lower adversity quotient more likely to perceive adversity as enduring, and those with higher adversity quotient possess an almost uncanny ability to see past even the direst circumstances [13]. According to Stoltz [5] the higher endurance tends to look the period of the obstacles faced only temporarily, so that it will not decreasing person's spirit to reach their goals. 
Based on the problems and the underlying theoretical framework of this research, the researchers put forward several hypotheses:

H1: control, origin \& ownership, reach, and endurance simultaneously have significant effect to entrepreneurial intention

$\mathrm{H} 2$ : control have significant effect to entrepreneurial intention

H3: origin \& ownership have significant effect to entrepreneurial intention

H4: reach have significant effect to entrepreneurial intention

$\mathrm{H} 5$ : endurance have significant effect to entrepreneurial intention

\section{RESEARCH METHODS}

This research used associative approach using a psychological factor to explain entrepreneurial intention on students in The Faculty of Economics and Business University of North Sumatera majoring in entrepreneurship.

The purpose of this research is to know and analyze the influence of control (X1), origin \& ownership (X2), reach (X3), and endurance (X4), partially and simultaneously against entrepreneurial intention $(\mathrm{Y})$. The following is the chart of the research design.

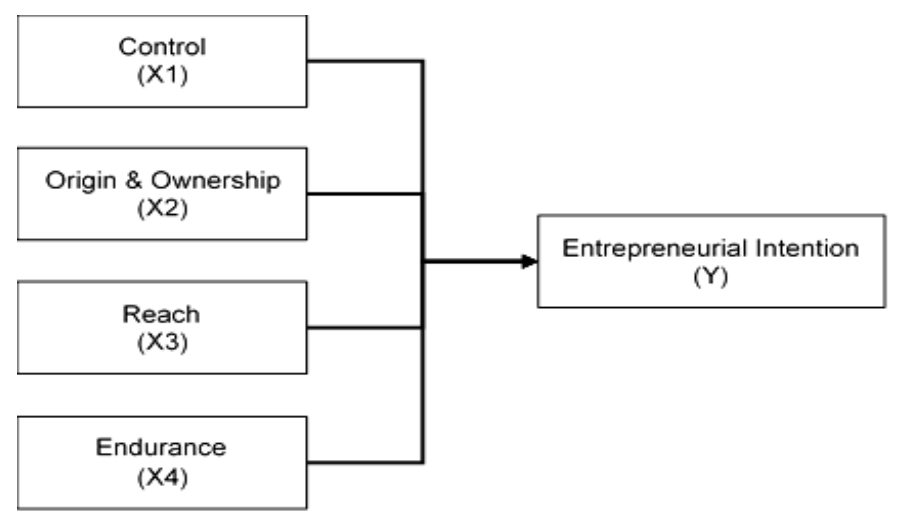

Figure 1. The Correlation between Variable

\section{A. Time and Location}

This research is conducted in the Faculty of Economics and Business University of North Sumatera. This study was conducted from February 2017 until July 2017.

\section{B. Population and Sample}

The population in this study is a student of management in the Faculty of Economics and Business University of North Sumatera, sampling method in this study using purposive sampling with the criteria of management students in batch 2013 and batch 2014 majoring in entrepreneurship up to 90 respondents.

\section{Data Collection}

In this study using primary data obtained from the questionnaires filling to 90 respondents, and using the secondary data such as study literature. The questionnaire in this research used a Likert scale with a range of scores 1-5 (strongly disagree - strongly agree) on each question.

\section{Data Analysis}

TABLE I. MULTIPLE LINEAR REGRESSION ANALYSIS

\begin{tabular}{|l|r|r|r|r|c|}
\hline \multirow{4}{*}{ Model } & \multicolumn{2}{|c|}{$\begin{array}{c}\text { Unstandardized } \\
\text { Coefficients }\end{array}$} & $\begin{array}{c}\text { Standardized } \\
\text { Coefficients }\end{array}$ & & \\
\cline { 2 - 4 } & \multicolumn{1}{|c|}{$\mathrm{B}$} & Std. Error & \multicolumn{1}{|c|}{ Beta } & \multicolumn{1}{c|}{ S } & Sig. \\
\hline 1 1 (Constant) & 20.134 & 4.188 & & 4.807 & .000 \\
\cline { 2 - 6 } Control (X1) & .605 & .272 & .298 & 2.224 & .029 \\
Origin \& Ownership (X2) & .024 & .225 & .012 & .105 & .916 \\
\cline { 2 - 6 } Reach (X3) & .031 & .244 & .017 & .129 & .898 \\
\cline { 2 - 6 } Endurance (X4) & .691 & .285 & .292 & 2.422 & .018 \\
\hline \multicolumn{2}{|l|}{ Source: Results of Data Processing (2017) }
\end{tabular}

$$
\mathrm{Y}=20.134+0.605 \mathrm{X} 1+0.024 \mathrm{X} 2+0.031 \mathrm{X} 3+0.691 \mathrm{X} 4+\mathrm{e}
$$

Based on the multiple regression equations, it can be seen the value of the control coefficient (X1) is 0.605 . the value indicates that every $1 \%$ increase in the control variable will increase the entrepreneurial intention by $0.00605 \%$. The value of the origin \& ownership coefficient (X2) is 0.024 , the value indicates that every $1 \%$ increase in the origin \& ownership variable will increase the entrepreneurial intention by $0.00024 \%$. The value of the reach coefficient (X3) is 0.031 . the value indicates that every $1 \%$ increase in the reach variable will increase the entrepreneurial intention by $0.00031 \%$. The value of the endurance coefficient (X4) is 0.691 . the value indicates that every $1 \%$ increase in the endurance variable will increase the entrepreneurial intention by $0.00691 \%$.

\section{RESUlts \& DisCUSSION}

\section{A. The Results of Simultaneous Significance Test}

$$
\text { TABLE II. F-TEST }
$$

\begin{tabular}{|c|c|c|c|c|c|}
\hline \multicolumn{6}{|c|}{ ANOVA $^{\mathbf{D}}$} \\
\hline Model & Sum of Squares & df & Mean Square & $\mathrm{F}$ & Sig. \\
\hline 1 Regression & 440.257 & 4 & 110.064 & 9.262 & .000 \\
\hline Residual & 1010.065 & 85 & 11.883 & & \\
\hline Total & 1450.322 & 89 & & & \\
\hline
\end{tabular}

Based on Table II, the result showed that F-value 9.262 $>2.479$ it means control, origin \& ownership, reach, and endurance simultaneously have significant effect to the entrepreneurial intention.

\section{B. The Results of Partial Significance Test}

\begin{tabular}{|c|c|c|c|c|c|}
\hline \multirow[b]{2}{*}{ Model } & \multicolumn{2}{|c|}{$\begin{array}{l}\text { Unstandardized } \\
\text { Coefficients }\end{array}$} & \multirow{2}{*}{$\begin{array}{c}\begin{array}{c}\text { Standardized } \\
\text { Coefficients }\end{array} \\
\text { Beta }\end{array}$} & \multirow[b]{2}{*}{$\mathrm{t}$} & \multirow[b]{2}{*}{ Sig. } \\
\hline & $\mathrm{B}$ & Std. Error & & & \\
\hline \multirow{5}{*}{$\begin{array}{ll}1 \text { (Constant) } \\
\text { Control (X1) } \\
\text { Origin \& Ownership (X2) } \\
\text { Reach (X3) } \\
\text { Endurance (X4) }\end{array}$} & 20.134 & \begin{tabular}{|l|}
4.188 \\
\end{tabular} & & 4.807 & .000 \\
\hline & .605 & .272 & .298 & 2.224 & .029 \\
\hline & .024 & .225 & .012 & .105 & .916 \\
\hline & .031 & .244 & .017 & .129 & .898 \\
\hline & .691 & .285 & .292 & 2.422 & .018 \\
\hline
\end{tabular}

TABLE III. T-TEST 
a. Dependent Variable: Entrepreneurial Intention (Y)

Based on Table III, the result showed control have significant effect to entrepreneurial intention because Sig. value on variable control is $0.029<0.05$. Origin \& ownership have insignificant effect because Sig. value is $0.916>0.05$. Also reach have insignificant effect to entrepreneurial intention because Sig. value is $0.898>0.05$. The endurance variable have significant effect, that Sig. value is $0,018<0.05$. It means endurance as dominant variable to influence the entrepreneurial intention.

\section{Coefficient of Determination $\left(R^{2}\right)$}

TABLE IV. COEFFICIENT OF DETERMINATION

Model Summary ${ }^{b}$

\begin{tabular}{|l|c|r|r|r|}
\hline Model & R & R Square & Adjusted R Square & Std. Error of The Estimate \\
\hline 1 & $.551^{\mathrm{a}}$ & .304 & .271 & 3.44716 \\
\hline
\end{tabular}
a. Predictors: (Constant), Control (X1), Origin \& Ownership (X2), Reach (X3), Endurance (X4)
b. Dependent Variable: Entrepreneurial Intention (Y)

Based on Table IV, the result showed $\mathrm{R}^{2}$ value is 0,304 . It means that adversity quotient contributed $30,4 \%$.

\section{Discussion}

1) The Influence of Adversity Quotient to Entrepreneurial Intention

Based on the results of simultaneously testing, the adversity quotient gives a significant effect to the entrepreneurial intention, which indicates the higher adversity quotient it has is raising up the entrepreneurial intention. The person who has high adversity quotient can reduce negative thinking such as thinking they are not able to solve the obstacles and thinking about bad things that will happen, so that person won't hesitate to decide becoming entrepreneur. This results in accordance with results of research Firmansyah et al [11] and Linan et al [8] which shows that adversity quotient has significant effect on the entrepreneurial intention.

\section{2) The Influence of Control to Entrepreneurial Intention}

Based on the results, control have a positive and significant effect to entrepreneurial intention. That is in line with the results [7,13]. That results indicate students very confident to overcome various obstacles that prevent them to become entrepreneur. The higher control can create confidence and more optimist to the students and make the impact to their entrepreneurial intention. According Hendro [2] it is because they are very good at managing their fears so as to generate courage and confidence. A person who feels more able to overcome the various obstacles will form a strong confidence and will be more optimist in reaching their goals.

\section{3) The Influence of Origin \& Ownership to Entrepreneurial Intention}

Based on the results, origin \& ownership have positive but insignificant effect to the entrepreneurial intention. That is in line with the results $[7,13]$. These results shows origin \& ownership can't influence entrepreneurial intention on students, however origin \& ownership need another variable to influence entrepreneurial intention on students such as control, reach, and endurance.

\section{4) The Influence of Reach to Entrepreneurial Intention}

Based on the results, reach have positive but insignificant effect to the entrepreneurial intention. That is in line with the results [7,13]. That results shows reach can't influence entrepreneurial intention on students, but reach can influence entrepreneurial intention if assisted with another variable such as control, origin \& ownership, and endurance.

\section{5) The Influence of Endurance to Entrepreneurial Intention}

Based on the results shows endurance is dominant variable influence the entrepreneurial intention. Endurance have positive and significant effect to the entrepreneurial intention; this results contradicted with research [7,13]. But in line with theory of adversity quotient, where [5] states a person who has good endurance has a strong spirit in achieving its goals despite being blocked by various obstacles and [2] said the success will come to the person who has strived to achieve it. Persistence is the main key that must be owned by people to succeed in realizing his dreams [2], so the higher endurance will raising up entrepreneurial intention in person because encurance can give more spirit to achieving his goal when the various obstacles prevent them continuously.

\section{CONCLUSION \& RECOMMENDATION}

\section{A. Conclusions}

1) The results showed control, origin \& ownership, reach, and endurance simultaneously has significant effect to the entrepreneurial intention on student in the Faculty of Economics and Business University of North Sumatera.

2) The results showed that partially origin \& ownership as well as reach have insignificant effect to the entrepreneurial intention, meanwhile control and endurance have significant effect to the entrepreneurial intention, endurance as the dominant variable to influence entrepreneurial intention on students in the Faculty of Economics and Business University of North Sumatera.

3) The coefficients of determination from adversity quotient is 0.304 . It means adversity quotient contributed $30.4 \%$ to explaining the entrepreneurial intention on students, while the rest $69.6 \%$ is explained by others.

\section{B. Recommendations}

1) Based on those conclusions, it is suggested that the schools increase the adversity quotient, to improve the entrepreneurial intention of the vocational students majoring in business and management. This will be 
very advantageous when the students graduate. It can help determine their career choice that leads to entrepreneurship. The school can directly and indirectly stimulate students' entrepreneurial intention through entrepreneurial learning and the other entrepreneurial supporting activities, such as a business consulting agency, fairs, entrepreneurial events, seminars, and other entrepreneurial supporting activities.

2) The other researchers hoping to conduct similar research are expected to involve other variables affecting entrepreneurial intention. Adversity quotient affecting entrepreneurial intention. This shows that there are other variables that can affect entrepreneurial intention. And, the indicators used in this research were adapted from the previous research. It is expected that the other researchers hoping to conduct similar research can use the indicators and instruments as needed.

3) The main conclusion drawn from this study relates to a better understanding of the profile comparison between students and employee in the field Entrepreneurial Intention and Adversity Quotient. In this regard, it appears that to become an Entrepreneurship University; there should be many activities such as trainings, coaching, etc. to enhance the entrepreneurial intention in the university students.

\section{REFERENCES}

[1] Hisrich, R. D., Peters, M. P., \& Shepherd, D. A. (2009). Kewirausahaan. Jakarta: Salemba Empat

[2] Hendro. (2011). Dasar-Dasar Kewirausahaan: Panduan Bagi Mahasiswa Untuk Mengenal, Memahami, dan Memasuki Dunia Bisnis. Jakarta: Erlangga.

[3] Puri, Y. S. (2013). Hubungan Antara Adversity Quotient Dengan Minat Berwirausaha Siswa Kelas XII Pemasaran Di SMKN 1 Surabaya. Jurnal Pendidikan Tata Niaga, 1.

[4] Zahreni, S., \& Pane, R. S. (2012). Pengaruh Adversity Quotient Terhadap Intense Berwirausaha. Jurnal Ekonom, 173-178.

[5] Stoltz, P. G. (2012). Adversity Quotient: Mengubah Hambatan Menjadi Peluang. Jakarta: Grasindo.

[6] Handaru, W. A., Parimita, W., \& Mufdhalifah, I. W. (20 built enterprenuer through Adversity Quotient, Self Efficacy, dan Need for Achievement. Jurnal Manajemen dan Kewirausahaan, 17, 145-166.

[7] Setyaningrum, N. (2009). Hubungan Adversity Quotient Dengan Intensi Berwirausaha Pada Karyawan. Jakarta: Universitas Indonesia.

[8] Linan, F., Cohard, J. C., \& Cantuche, J. M. (2011). Factors Affecting Entrepreneurial Intention Levels: A Role for Education. International Entrepreneurship and Management Journal, 195-218.

[9] Krueger, N. F., Reilly, M. D., \& Carsrud, A. L. (2000). Competing Models of Entrepreneurial Intentions. Journal of Business Venturing, 411-432.

[10] Sagiri, S., \& Appolloni, A. (2009). Identifying The Effect of Psychological Variables On Entrepreneurial Intentions. DSM Business Review, 61-86.

[11] Firmansyah, A. H., Djatmika, E. T., \& Hermawan, A. (2016). The Effect of Adversity Quotient and Entrepreneurial Self-Efficacy on Entrepreneurial Intention Through Entrepreneurial Attitude. Journal of Business and Management, 45-55.

[12] Riyanti, B. P. (2010). Kewirausahaan Dari Sudut Pandang Psikologi. Jakarta: Grasindo.
[13] Mangundjaya, W. H. (2009). The Relationship of Resilience and Entrepreneurial Intentions. Proceedings International Entrepreneurship Congress SMEs and Entrepreneurship (pp. 1-5). Turkey: ResearchGate. 